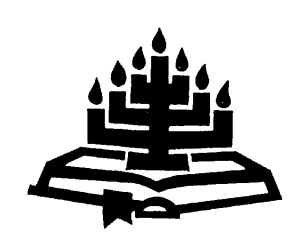

\title{
'n Ekklesiologiese model vir die bediening van versoening in 'n sosio-politieke konteks
}

\author{
J.M. Vorster \\ Skool vir Kerkwetenskappe \\ Potchefstroomkampus \\ Noordwes-Universiteit \\ POTCHEFSTROOM \\ E-pos: koos.vorster@nwu.ac.za
}

\begin{abstract}
An ecclesiological model for the ministry of reconciliation in a socio-political context
\end{abstract}

This research article examines an ecclesiological model suitable for the promotion of socio-political reconciliation in the South African context from a reformed theological and philosophical pespective. Its point of departure is that reformational theology is per definition a public theology, which is inter alia directed at the renewal of society, and that churches have a positive role to play in this regard. Firstly, the article investigates the historic contribution of Kuyper's ecclesiology and Dooyeweerd's perspective on social life and the philosophy of the Idea of Law. Secondly, the article focuses on the biblical concept "Kingdom of God" and its implications for an ecclesiological model. Taking into account the contributions of these two lines of thought, the article concludes that the church should be seen as the "power station" of society. The church should equip believers to promote socio-political transformation in society. Furthermore, the church should be actively engaged in sociopolitical transformation by preaching the reconciliation in Christ and its implications for society, and by being an example of reconciliation amidst a divided community by overcoming the divisions caused by racism, tribalism, sexism, xenophobia, homophobia and ethnocentrism in its own midst. 


\section{Opsomming}

\section{'n Ekklesiologiese model vir die bediening van versoening in 'n sosio-politieke konteks}

Hierdie navorsingsartikel ondersoek, vanuit 'n gereformeerde perspektief, 'n moontlike ekklesiologiese model wat geskik is om sosio-politieke versoening in die Suid-Afrikaanse konteks te bevorder. Die uitgangspunt is dat gereformeerde teologie per definisie 'n publieke teologie is, omdat dit onder andere die reformasie van die samelewing in die oog het. Eerstens behandel die artikel die historiese bydrae van die ekklesiologiese model van Kuyper en die bydrae van die reformatoriese filosofie, by name die "Wysbegeerte van die wetsidee". Tweedens fokus die ondersoek op die bybelse konsep "koninkryk van God" en die implikasies daarvan vir die ekklesiologiese model. Met hierdie perspektiewe as uitgangspunt word tot die konklusie gekom dat die geïnstitueerde kerk as die "kragstasie" van die samelewing gesien moet word. Die kerk moet gelowiges toerus om sosio-politieke reformasie van die samelewing te bevorder. Die geïnstitueerde kerk moet ook self by sosiopolitieke reformasie betrokke wees deur die prediking van die versoening en die sosio-politieke betekenis daarvan. As gemeenskap van gelowiges moet dit die voorbeeld van versoening wees deur die grense van rassisme, xenofobie, homofobie, seksisme en etnosentrisme te oorkom.

\section{Inleiding en probleemstelling}

Die Christelike teologie het na die Tweede Wêreldoorlog die fokus al hoe meer laat val op die sosio-politieke betekenis van die evangelie en die kosmologiese roeping van die kerk. Dit is gedoen te midde van 'n groeiende protesateïsme en 'n besef dat die kerke nie oplossings bied vir die na-oorlogse sosiale problematiek nie, maar dikwels eerder deel van die probleem is. Besware is teen die kerke se beweerde ondersteuning aan die Nasionaal-Sosialisme uitgespreek (Praamsma, 1981:170), die Rooms-Katolieke Kerk se vermeende stilswye oor die Duitse konsentrasiekampe, die Russies-Ortodokse Kerk se onderdanigheid aan die Stalin-regime (Cairns, 1982:438; Walker, 1992:681) en kerke se steun aan die apartheidstelsel in Suid-Afrika. In die drie dekades ná die oorlog het allerlei versetteologieë algaande die lig gesien, wat 'n teologiese ondersteuning wou bied vir revolusionêre politieke veranderingstrategieë in lande met diktatoriale en onderdrukkende regerings. Voorbeelde van hierdie teologieë is die teologieë van sekularisasie (Cox, 1967), transformasie (Verkuyl, 1971), revolusie (Shaull, 1969), bevryding (Gutierrez, 1974; 1985), swart teologie (Cone, 1970) en politieke teologie (Fier- 
ro, 1977). Hoewel die teologie van Moltmann nie as 'n versetteologie beskryf kan word nie, het sy teologie van die Hoop ook in hierdie kringe die verbeelding aangegryp (vgl. Moltmann, 1965; 1994; 2008).

Die versetteologieë het intussen stoom verloor, maar die aandrang op 'n aktuele teologie wat op sosio-politieke geregtigheid en vrede gerig is, en wat besig wil bly met die makro-etiese vraagstukke van die tyd, is steeds sterk. Hierdie tendens blyk uit die konstante aandag wat vir die ontwikkeling van publieke teologie gevra word. Wat daarmee bedoel word, word duidelik in Smit (2007) se grondige studie uiteengesit waarin hy met verskeie ander eksponente van hierdie terminologie in gesprek is.

In die lig van Smit se verduideliking van publieke teologie, kan die stelling gemaak word dat die teologie van die reformatoriese Reformasie, en soos dit ná Calvyn verder ontwikkel is, eintlik publieke teologie is. Calvyn (1949) het die laaste hoofstuk van sy Institusie immers aan die rol van die Christelike geloof in die samelewing gewy toe hy die taak van die burgerlike owerheid beskryf het. Hy is hierin nagevolg deur die opstellers van die Heidelbergse Kategismus, wat in die derde deel van die Katagismus op die wet as die reël van dankbaarheid en op die kosmiese betekenins van die gebed gewys het, asook die Nederlandse Geloofsbelydenis. Calvyn se invloed op die samelewingskritiek van staatkundiges soos Grotius, Locke, Groen van Prinsterer, die vryheidstryders in Amerika en die Vryburgers in Suid-Afrika is bekend. Gereformeerde teologie is per definisie 'n publieke teologie wat die diens aan God uit die geestelike en kerklike institutêre domein van die pre-reformatoriese tyd in 'n konkrete sosiaal-maatskaplike en politieke etiek wou laat realiseer.

Hoe moet die kerk en die gelowiges hierdie rol vervul? Watter ekklesiologiese model gee die beste uitdrukking aan die vervulling van hierdie roeping? Watter samelewingsleer is hier ter sprake? ${ }^{1}$ Hoe

1 Die bekende filosoof en kundige op die reformatoriese samelewingsfilosofie, B.J. van der Walt, dui in baie van sy publikasies aan dat die onvermoë van die reformatoriese lewens- en wêreldbbeskouing om die samelewing te transformeer, soos wat dit veral die geval is in Afrika, te wyte is aan die gebrek aan 'n Skrifgefundeerde samelewingsfilosofie. Hy beroep hom op soortgelyke analises van verskeie kundiges in internasionale verband soos Fowler uit Australië, Adeyemo uit Afrika, McCarthey en Wolters uit die VSA en Son uit Korea (Van der Walt, 2008a:2). Die rede vir die oneffektiwiteit van kerke in die vervulling van hulle maatskaplike roeping (ook dus ten opsigte van sosio-politieke versoening - JMV) lê vir hom daarin dat gelowiges die Skrif óf privatiseer, óf monopoliseer. 
moet die gereformeerde teologie, met behoud van sy karakter van sola deo gloria, sola gratia, solus Christus, sola scriptura en sola fide, vandag funksioneer as 'n teologie wat die hele mens en die hele samelewing aktueel betrek? Hoe moet hierdie roeping van kerke en gelowiges vandag in sosio-politieke versoening realiseer? Hierdie vrae is tans baie aktueel in die huidige Suid-Afrikaanse konteks.

Tog is die behandeling van hierdie problematiek nie vreemd aan die gereformeerde teologie nie. Dit was veral Kuyper wat oor 'n ekklesiologiese model vir die samelewingsbetrokkenheid van gereformeerde teologie begin besin het met die aanslag van die revolusionêre denke van die Verligting in gedagte. Sy gedagtes het neerslag gevind in sy bekende Stone Lectures (1899) by die Princeton Universiteit in die VSA. Dit het ook 'n diep indruk gemaak op die gereformeerde kerklike tradisies in die VSA, Nederland en SuidAfrika (vgl. Kuyper, 1943). Hy wou 'n ekklesiologiese model daarstel wat instrumenteel vir die samelewingsbetrokkenheid van gereformeerde teologie kan wees. Die aanslag van sekularisme het sedertdien net verder toegeneem en die vraag wat Kuyper gestel het, is tans nog net so aktueel as in sy tyd. Ten opsigte van die eietydse problematiek kan die vraag vandag soos volg geformuleer word: Watter ekklesiologiese model bied die ruimte vir die gereformeerde teologie om vandag as gefundeerde en 'n probleem-oplossende teologie sosio-politieke versoening in Suid-Afrika te bevorder?

Hierdie vraag is die fokuspunt van hierdie navorsingsartikel. Die sentraal-teoretiese argument van hierdie studie lui soos volg: Met die koninkryksgedagte as ekklesiologiese model kan die gereformeerde teologie as 'n relevante publieke teologie funksioneer wat sosio-politieke versoening in die sekulariserende samelewing in Suid-Afrika vandag effektief kan bevorder. Die argument word ontwikkel deur die historiese argumentasielyn te volg soos dit deur

Privatisering van die Skrif beteken dat hulle die Skrif slegs op die "persoonlike en kerklike lewe" betrek en nie op die breë terrein van die samelewing nie. Monopolisering van die Skrif beteken dat hulle alles slegs uit die Skrif wil aflei en die volle openbaring van God buite rekening laat. Van der Walt sien die antwoord daarin dat die gelowige die eenheid en heelheid van die Skrif hanteer en ook die skeppingsopenbaring van God ter harte neem. Met so 'n holistiese Skrifbeskouing en -hantering kan 'n verantwoordelike samelewingsfilosofie ontwikkel word. Hy lewer self 'n groot bydrae hiertoe en sy publikasies kan beskou word as die grootste bydrae wat tans wêreldwyd hieroor aan die orde is (vir 'n samevatting hiervan, vgl. Van der Walt, 2008a:11). 
Kuyper aan die orde gestel, en daarna verder ontwikkel is in sowel die reformatoriese filosofie as die gereformeerde teologie.

\section{Die geïnstitueerde kerk en die samelewing}

Die verband tussen die volk van God op aarde, die geïnstitueerde kerk en die samelewing het in die kringe van die reformatoriese tradisie deurlopend aandag geniet. Die tendens was juis die gevolg van die reformatoriese ekklesiologie se verset teen die RoomsKatolisisme se dualisme tussen die ryke van natuur en genade en die daaruit voortvloeiende skerp skeiding tussen kerk en wêreld, wat gelei het tot kerklike institusionalisme en die sekularisering van die samelewing. Om die hele ontwikkeling binne die reformatoriese denke in hierdie verband in één artikel te probeer behandel, sal daaraan afbreuk doen. Om egter, ter wille van prinsipiële kriteria, in hierdie verband 'n standpunt te stel oor die roeping van die geïnstitueerde kerk met betrekking tot sosio-politieke versoening in die samelewing, moet daar op hierdie reformatoriese tradisie voortgebou word. Met inagneming van die begrensing vir hierdie studie en die nodigheid van die reformatoriese tradisie vir verdere beredenering, word in die volgende uiteensetting op die hoofmomente in die tradisie gefokus. Daarna word meer op resente ontwikkelings in hierdie verband toegespits (vgl. ook Van der Walt, 2008a:15; 2008b:513).

Die bespreking van die hoofmomente begin by 'n kort ontleding van Kuyper se ekklesiologie. Daarna word verdere besinning in die samelewingsleer van die wysbegeerte van die wetsidee bespreek met 'n toespitsing op Dooyeweerd se standpunt en die verdere uitbouing daarvan in Suid-Afrika. Hierdie ontwikkeling het vir 'n lang tyd 'n wesenlike invloed uitgeoefen op die siening van die kosmologiese roeping van kerke in die gereformeerde tradisie in SuidAfrika. Vervolgens word die aandag bepaal by die besinning oor ' $n$ ekklesiologiese model in die reformatoriese teologie waarin die roeping van die kerk tot sosio-politieke versoening binne die perspektief van die gedagte van die koninkryk van God beredeneer word.

\section{Kuyper oor instituut en organisme}

Die onderskeiding wat Kuyper getref het tussen die sigbare en die onsigbare kerk is alombekend. Dit was vir 'n lang tyd die gangbare opvatting in die gereformeerde ekklesiologie. Om te verstaan wat hy daarmee bedoel, moet daar eintlik onderskei word tussen twee fases in Kuyper se denke hieroor. Aanvanklik het Kuyper (1892:134) 
dit gesien dat die onsigbare kerk die uitverkore gelowiges oor die hele wêreld en oor alle tye omvat. Die sigbare kerk is die instelling waardeur die diens van die Woord en die sakramente kan plaasvind. "Meer is de zichtbare kerk niet. Ze is eenvoudig een Instituut voor den Dienst des Woords." Die instituut op sigself het dus nie 'n rol te speel in die samelewing nie.

In 'n latere stadium het Kuyper 'n ander onderskeiding gehandhaaf. Hy het toe steeds tussen die onsigbare en die sigbare kerk onderskei, maar dit so beredeneer dat die onsigbare kerk die sooma van Christus is vir sover dit verborge is (Kuyper, 1909a:205). Hiervoor het hy hom veral op die Westminster Konfessie beroep (Kuyper 1943:61). Die sigbare kerk, daarenteen, is al die gelowiges soos hulle op ' $n$ bepaalde tyd in die wêreld teenwoordig is. Hierdie sigbare kerk het twee bestaansvorms, naamlik die kerk as organisme en die kerk as instituut (Kuyper, 1909b:204). Die instituut is die amptelike organisasie van gelowiges "voor zoover ze door afzonderlijke inrichting tot een specifieke formatie is gekomen". Die instituut is dus die sigbare organisasie van gelowiges soos wat dit in plaaslike kerke en meerdere vergaderings georganiseer word. Die organisme beskryf die gelowiges soos hulle funksioneer in die tydelike samelewingsverbande soos die huwelik, die gesin, die staat en die verenigingslewe. Die roeping van die kerk as instituut word beperk tot die diens van Woord en sakramente, terwyl die kerk as organisme (dit wil sê die gelowiges) die uitbreiding van die ryk van Christus op alle samelewingsvlakke ten doel het.

Hierdie onderskeidings het 'n besondere inslag gevind in die reformatoriese ekklesiologie. Buys (1970:144) gee 'n goeie oorsig daarvan in sy studie waarin hy die ekklesiologiese onderskeiding van instituut en organisme beskou as 'n ekklesiologiese korrektief op die apostolaatsteologie van Van Ruler. Die belangrikste invloed van Kuyper se beskouing lê daarin dat die rol wat die geïnstitueerde kerk in die samelewing kan speel beperk is tot die diens van Woord en sakramente binne die erediens. Die gevolg van hierdie ekklesiologiese model is dat die geïnstitueerde kerk nie op die terreine van samelewing en politiek moet figureer nie, en by meerdere vergaderings ook alleen aan "kerklike sake" aandag kan gee. Kerklike sake is gedefinieer as sake wat die kerk direk raak (vgl. Vorster, 1993: 224). Volgens hierdie ekklesiologiese model kan die geïnstitueerde kerk nie op enige wyse, anders as deur die prediking in die plaaslike kerk, betrokke wees in die bevordering van sosio-politieke versoening in die samelewing nie. Dit, tesame met die invloed van die 
Metodisme, $\mathbf{2}$ verklaar die terughoudendheid van die drie Afrikaanse kerke in Suid-Afrika in die verlede om 'n duidelike profeties-kritiese getuienis teenoor die etiese onhoudbaarheid van apartheid te laat hoor. Kuyper se ekklesiologiese onderskeid is ook verder uitgebou in die samelewingsleer van die reformatoriese filosofie en dit het die invloed van hierdie ekklesiologiese model in Suid-Afrika versterk. Hierop word vervolgens gewys.

\section{Die ekklesiologiese model van die reformatoriese filosofie}

Die denke van die invloedryke Nederlandse filosoof Dooyeweerd en sy volgelinge in Suid-Afrika oor die kerk, is in ooreenstemming met Kuyper se ekklesiologie. Hy het, met die ondersteuning van die Suid-Afrikaanse filosoof Stoker, binne die raamwerk van hulle onderskeie filosofiese samelewingsbeskouings verder hieroor besin. Dit is reeds deur onder andere die teoloog Schilder (s.a.:97) en die filosoof Botha (1971:136) bespreek en na waarde geskat.

In sy uiteensetting van die kerk as samelewingsverband naas ander samelewingsverbande, onderskei Dooyeweerd (1936:451), soos Kuyper, ook tussen die ecclesia invisibilis en die ecclesia visibilis. Hy gebruik hierdie terme, alhoewel hy duidelik laat blyk dat hy nie heeltemal gelukkig is daarmee nie, omdat dit te maklik die idee skep van twee heel afsonderlike kerke. Hy sien die ecclesia invisibilis as die religieuse wortelgemeenskap in Christus wat bo-tydelik is (Dooyeweerd, 1936:480). Die ecclesia visibilis bevat al die tydelike menslike samelewingstrukture. Een van hierdie tydelike samelewingstrukture is die kerkinstituut. Die ecclesia visibilis bestaan dus uit al die tydelike samelewingsverbande soos die Christelike staat, Christelike gesin en onder andere ook die geïnstitueerde kerk.

Die verhouding tussen die geïnstitueerde kerk en die ander verbande is gelykwaardig, omdat almal 'n gemeenskaplike religieuse wortel

2 Die Metodisme van die agtiende eeu het teenoor die Rasionalisme van die Verligtingsdenke die boodskap van die Skrif betrek op die "sieleheil" van die mens en so geen ruimte gelaat vir die samelewingbetekenis van die teologie nie. Die Metodisme in Suid-Afrika het dus 'n piëtistiese lewensbenadering tot gevolg gehad waarin die kerk vereng is tot ' $n$ "instituut vir die redding van siele". Hoewel die missionêre betrokkenheid van hierdie rigting positief waardeer moet word, het dit egter 'n uiters verskraalde siening nagelaat oor die rol wat die kerke in die bevordering van geregtigheid in die samelewing moet speel. Die metodistiese ekklesiologiese model het nie die nodigheid van 'n profeties-kritiese benadering tot apartheid ingesien nie. 
het, naamlik die ecclesia invisibilis. Die tydelike strukture is ook onderling onvervangbaar. Elkeen is "soewerein in eie kring" met 'n eie bestemmingsfunksie. Die bestemmingsfunksie van die geïnstitueerde kerk lê vir hom in die pistiese, en daarom is dit "die moeder van ons geloof in Jesus Christus" (Dooyeweerd, 1936:481). In hierdie opsig meen hy dat hy aansluit by Calvyn en Kuyper. Dooyeweerd (1936:485) sê sodra die tydelike geïnstitueerde kerk se "soewereiniteit in eie kring" geskend word, lei dit tot deformasie van die kerk. Deformasie van die kerk tree dus in wanneer daar sprake is van grensoorskryding van ander samelewingsverbande op die terrein van die geïnstitueerde kerk, of deur die geïnstitueerde kerk op die terreine van ander samelewingsverbande. Hy gee dus aan die geïnstitueerde kerk 'n eie, maar tog duidelik begrensde struktuur en funksie ten opsigte van die ander samelewingsverbande. Dit is, wat struktuur aanbetref, 'n "belydeniskerk" wat deur die diens van Woord en sakramente geloof moet laat groei. Dooyeweerd se duidelike afbakening van die begrensde taak van die geïnstitueerde kerk en sy siening van deformasie beteken dus dat die geïnstitueerde kerk nie op die terrein van die staat of ander samelewingsverbande mag beweeg nie, en dus nie 'n taak het ten opsigte van sosio-politieke versoening nie.

Die Suid-Afrikaanse filosoof Botha (1971:156) bou krities voort op Dooyeweerd se standpunt. Sy kritiseer, saam met ander, Dooyeweerd veral vir sy onkritiese oorname van "gereformeerde skolastiese" elemente van Kuyper se denke. Sy het dit veral teen die dichotomistiese opvattings van sigbaar-onsigbaar, algemeen-besonder, en instituut-organisme. Botha (1971:161) sien 'n uitweg daarin dat die saak uit die perspektief van die koninkryk benader moet word. Met hierdie beskouing het sy 'n groot bydrae gelewer. Ongelukkig gee sy nie 'n uiteensetting van wat sy onder die koninkryk in wysgerige sin verstaan nie. Omdat hierdie benadering 'n nuwe ontwikkeling ook in die reformatoriese wysbegeerte is, is dit moeilik om te bepaal vanuit watter koninkryksbeskouing sy redeneer. Dit blyk egter dat sy by implikasie beweer dat dit in die koninkryk gaan om die heerskappy van Christus. Die koms van die koninkryk beteken die baanbreking van die heerskappy van die wet van Koning Jesus Christus.

Die verbondsrelasie tussen die mens en Christus staan sentraal in hierdie opset. Dit impliseer ook 'n relasie met die medemens: "in gemeenskap met die Hoof ontstaan en bestaan daar ook tussen die lede onderling gemeenskap" (Botha, 1971:163). Botha sê dat dit juis hierdie onderlinge gemeenskap is wat in die Bybel met die beeld, 
liggaam van Christus, uitgebeeld word. Hierdie ondelinge gemeenskap kry konkrete gestalte in die kerk en dit maak van die kerk meer as net die tydelike geloofsinstituut. Maar die ondelinge gemeenskap in Christus kry ook gestalte in alle intermenslike relasies, dit wil sê in die samelewing. Haar standpunt is dus dat die liggaam van Christus, as diegene wat in 'n verbondsrelasie aan Christus gebind is, gestalte kry in alle intermenslike relasies (samelewingsverbande) wat, in gehoorsaamheid aan die wet van God en afgestem op die koms van die koninkryk, ontstaan het.

Benewens dit wat reeds gesê is oor Botha se standpunt, moet daar verder instemming betuig word met haar beklemtoning van die verbondsgemeenskap wat gestalte kry in alle intermenslike relasies. Sy ontkom daarmee nie alleen aan die dichotomistiese opvattings van Dooyeweerd nie, maar sy gee ook meer ruimte aan die geïnstitueerde kerk om betrokke te raak by sosio-politieke versoening sonder dat so 'n betrokkenheid as deformasie afgewys kan word. Hierdie beklemtoning van die verbondsgemeenskap as religieuse wortel van die geïnstitueerde kerk maak ook Buys (1970:190) se kritiek op die reformatoriese filosofie ongeldig wanneer hy sê dat die samelewingsleer van hierdie filosofie "onskriftuurlik en eksegeties onbewysbaar" is. Vanuit die gedagte van die verbondsgemeenskap is daar beslis 'n saak voor uit te maak dat die liggaam van Christus gestalte kry in die Christelike samelewingsvorms waarvan die geïnstitueerde kerk een is, en dat almal betrokke moet wees by die realisering van die versoening wat Christus teweeg gebring het.

In sy belangwekkende boek wat in 1962 verskyn het, oefen Duvenage ook kritiek uit op die Kuyperiaanse onderskeiding instituutorganisme. Sy kritiek is nie soseer gemik teen die saak nie, maar teen die terme. Die terme lei daartoe, volgens hom, dat die sake eintlik teenoor mekaar gestel word en selfs geskei word. Verder sê hy ook dat die instituut wel ook organies kan wees. Hy sê verder:

Om die saak dus suiwer te stel moet die kerk as instituut, beter gestel, die geïnstitueerde kerk, gesien word as een deel of een vorm van die kerk as organisme wat in allerlei gestaltes tot openbaring kom in hierdie bedeling. Die geïnstitueerde kerk sou genoem kon word die sentrale gestalte van die kerk as organisme. Daaruit blyk dan dat nie die kerk as instituut vereenselwig kan word met die sigbare kerk nie, maar wel die kerk as organisme, waarvan die instituut een openbaringsvorm is. (Duvenage, 1962:63.) 
In hierdie werk het Duvenage nog sterk aangeleun teen die standpunt van die wysbegeerte van die wetsidee, maar hy wil eerder praat van die sigbare en onsigbare aspekte van die kerk. Hiervoor sluit hy ook aan by die Westminster Konfessie. Die onsigbare aspek van die kerk sluit drie sake in:

Eerstens die kerk se bo-tydelike oorsprong (uitverkiesing), tweedens die bo-tydelike grondvester Christus, wat as tweede Adam die Verlosser en Koning van sy kerk is, en derdens die bo-tydelike vervulling in die voleinding van die eeue, wanneer die ontelbare skare die nuwe aarde sal beërwe. (Duvenage, 1962:53-55.)

Die sigbare kerk sien hy as die tydelike aspek van die onsigbare kerk:

Dit moet gesien word as die geheel van die openbaring van die onsigbare kerk of die koninkryk van die hemele in die tyd en dit omvat alle vergestaltinge van die lewe uit Christus. Daartoe behoort dus die Christelike huwelik, Christelike gesin, die Christelike staat, die Christelike skool, die Christelike kerkinstituut ensovoorts. (Duvenage, 1962:63.)

Die geïnstitueerde kerk is dan een deel of een vorm van die kerk. Dit is die sentrale gestalte van die kerk. In 'n later werk (Duvenage, 1969) het hy die gedagte van die koninkryk sterker na vore gebring. Hierop word later teruggekom.

Niemand uit die tradisie van die reformatoriese filosofie het egter soveel bygedra tot die ontwikkeling van die samelewingsfilosofie van hierdie rigting soos B.J. van der Walt nie. Sy talle publikasies hieroor in verskillende tale getuig hiervan. Hy handhaaf die gedagte van soewereiniteit in eie kring saam met sy pleidooi vir strukturele en konfessionele pluralisme (Van der Walt, 2008a:14) teenoor die samelewingsbeskouings van die Individualisme en die Kollektivisme (Van der Walt, 2008b:502). As vertrekpunt stel hy, onder andere, dat elke samelewingsverband binne sy eie sfeer 'n eie bevoegdheid en eiesoortige gesag en mag het, maar dat dit beperkte gesag en mag is. God alleen het absolute gesag en mag oor mens en samelewing. Binne elke verband geld ' $n$ eie gesag en ampsbeskouing wat deur die oorkoepelende gehoorsaamheid aan God gekwalifiseer word (Van der Walt, 2008b:508). Hy behandel die kerk volgens 'n struktuuranalise eie aan Dooyeweerd se modaliteitsleer en noem dat 'n kerk sosiaal, juridies en ekonomies kan optree, hoewel die wyse daarvan verskil van sodanige optrede deur die staat. Hiermee beweeg hy verder as die samelewingsfilosofie van Kuyper en die wys- 
begeerte van die wetsidee wat die rol van die geïnstitueerde kerk beperk het tot die bediening van Woord en sakramente. Volgens sy beskouing sou dit dus binne die roeping van die geïnstitueerde kerk lê om te protesteer op juridiese vlak teen byvoorbeeld die sosiale stratifikasie wat in Suid-Afrika in swang was. Hy noem ook dat daar in die gestruktureerde Christelike aksies groot potensiaal tot samelewingsverbetering lê (Van der Walt, 2008b:525).

Die aandag wat die gereformeerde teologie in Suid-Afrika in die afgelope vier dekades aan die betekenis van die Skriftuurlike begrip, koninkryk van God, gegee het, het nuwe perspektiewe vir die ekklesiologiese model oopgemaak. Hierdie insigte is in die reformatoriese filosofie en die gereformeerde teologie met vrug toegepas. Hierdie Skriftuurlike konsep word nou aan die orde gestel vir soverre dit van toepassing is op die ontwikkeling van 'n ekklesiologiese model wat instrumenteel kan wees vir die geïnstitueerde kerk se roeping tot sosio-politieke versoening in Suid-Afrika vandag.

\section{Die gereformeerde teologie oor koninkryk en kerk}

\subsection{Die koninkryk van God}

Drie invoedryke teologiese werke in die sestigerjare van die vorige eeu het die saak van die koninkryk van God opnuut aan die orde gestel en tot nuwe navorsing gelei oor hierdie tema en die betekenis daarvan vir die ekklesiologie en etiek, naamlik die werke van Van der Walt (1962), Bright (1963) en Ridderbos (1969). 3 Teenoor die invloedryke non-eskatologiese interpretasie van die koninkryk deur Ritsch, Schweitzer en Weiss het hierdie werke die "reeds" en die "nog nie" van die koninkryk aan die orde gestel. 4 Hierdie interpretasie van die koninkryk as 'n teenswoordige maar onvoltooide werklikheid is veral deur die gereformeerde teologie oor die afgelope dekades verder uitgebou. Die besondere beklemtoning van die koninkryk in hierdie kring spruit uit die aanvaarding dat die gedagte van die koninkryk van God 'n sentrale motief in die Bybel is. Bright (1963:7) het hierdie beskouing goed verwoord met sy bekende

In die gereformeerde teologie in Suid-Afrika is die nuwe navorsing oor die koninkryk op 'n besondere en vernuwende wyse toegepas as 'n nuwe paradigma vir die Etiek (bv. Heyns, 1986 en Van Wyk, 1991), Missiologie (Floor, 1974; Bosch, 1991), Ekklesiologie (Heyns, 1977; Spoelstra, 1989; Coertzen, 1991; Strauss, 1992 en Du Plooy, 1997) en Praktiese Teologie (De Klerk, 1987).

$4 \quad$ Vir 'n bespreking van hierdie ontwikkelings, vergelyk Ladd (1961:25) en Van der Walt (1969:105). 
stelling: "For the concept of the Kingdom of God involves, in a real sense the total message of the Bible". Die geldigheid van sy standpunt kry nie hier verdere aandag nie. Vir 'n beoordeling en bespreking daarvan word verwys na König (1988:355) en Van Rooy (1976:8).

Ridderbos (1969:307) betoog in sy boek dat die koninkryk 'n alomvattende gesigspunt verteenwoordig. Dit beteken die voleinding van die ganse geskiedenis, dit bring genade en gerig, het kosmiese afmetings en vervul tyd en ewigheid. Op 'n ander plek in dieselfde boek (Ridderbos, 1969:41-43) sê hy dat die begrip heerskappy die wesenlike betekenis van die koninkryk is, en dat die ruimtelike betekenis sekondêr is. Van der Walt (1962:32) waarsku egter sterk teen enige vereensydiging of sisteemdwang wanneer dit kom by die omskrywing van die koninkryk. Sy eie omskrywing, wat hy op goeie eksegetiese en openbaringshistoriese gronde bou, is daarom, myns insiens, gebalanseerd en dit kan gebruik word as die grondslag vir die verdere beredenering in hierdie uiteensetting. Sy omskrywing lui:

Die Koninkryk is iets wat kom (Matt. 6:10 par.; Luk. 11:2, ensovoorts.), en wel tot mense (Matt. 12:28 par.) - maar dis ook iets waartoe mense kom en ingaan (Matt. 5:20; 7:12; 18:3; Mark. 9:47, ens.) en terselfdertyd ook 'n plek of 'n 'sfeer' (Matt. 5:19; Matt. 8:11; Luk. 13:28, ensovoorts). (Van der Walt, 1962:32.)

Hy sê verder dat die gedagte van die heilryke soewereiniteit van God eerstens as daad, tweedens as terrein en derdens, dit wat in die magsuitoefening gebeur, grondliggend is (Van der Walt, 1962: 33). Hierdie omskrywing word ook met instemming deur die Nuwe Testamentikus Floor (1974:1) aangehaal en Vorster (2006:740) gebruik hierdie uitgangspunt om die transformerende en dinamiese aard van die koninkryk te beklemtoon.

Vir die doeleindes van hierdie artikel is dit nie nodig om op al bogenoemde aspekte van die koninkryk in te gaan nie. Die aspekte wat vir die uiteensetting van 'n ekklesiologiese model nodig is en wat verdere besinning vereis, is die begrippe koningskap in die koninkryk, die mens in die koninkryk en die kerk in die koninkryk.

\subsection{Koningskap in die koninkryk}

Hoewel die begrip koninkryk van God nie in die Ou Testament aangetref word nie, kom die saak tog duidelik daarin na vore. In die Ou Testament word baie klem gelê op die regering of heerskappy van God oor sy volk en die oorwinning deur daardie volk aan die 
einde van die geskiedenis (Du Toit, 1969:12). Dat die saak 'n belangrike Ou-Testamentiese konsep is, blyk daaruit dat Jesus die begrip koninkryk van God self nooit kwalifiseer wanneer Hy dit gebruik nie. Daaruit moet afgelei word dat Hy dus met 'n saak werk wat reeds bekend moes gewees het (Van der Walt, 1962:33). In die Nuwe Testament word die woord basileia (koninkryk) dikwels aangetref. In sy etimologiese en teologiese verklaring van die begrip sê Schmidt (1969a:579) dat die begrip eerstens op die wese of natuur van die koning wys. Daar word dus in sowel die Ou Testament as die Nuwe Testament in die uiteensetting van die saak van die koninkryk van God baie klem op die koning en op sy heerskappy gelê.

Om 'n duidelike beeld van die aard, gestalte en reikwydte van die koningskap te gee, moet die saak vanuit 'n openbaringshistoriese oogpunt benader word. In hierdie opsig het Postma (1969:59) 'n bruikbare bydrae gelewer. Hy sê dat daar in die Bybel onderskei moet word tussen tweërlei tipes koningskap, naamlik die koningskap van God drie-enig soos dit onder andere uitgedruk word in Psalm 93:1 en 1 Timoteus 1:17 en die koningskap van Christus soos dit onder andere uitgedruk word in Jesaja 9:5, Matteus 2:2 en Lukas 1:33. Op grond van die gegewens van Efesiërs $5: 5$ sê hy dat daar wel ook ' $n$ innige verband is, maar tog ook 'n onderskeid. Hierdie onderskeid bring hy aan die lig met 'n openbaringshistoriese ondersoek.

In verband met die koningskap van God drie-enig, sê Postma (1969:61-65) dat God drie-enig die eintlike Koning is op grond van die skepping van hemel en aarde. Sy koningskap behels die onderhouding en regering van alle dinge. Met die skepping van alle dinge word die mens deur God aangestel as onderkoning (Gen. 1:26). Die mens moet alles op sorgsame wyse beheers. God wil sy koningskap regstreeks uitoefen deur middel van die mens. Hiervoor beroep Postma hom op Psalm 8:7. Met die sondeval is hierdie koningskap van God egter versteur, hoewel nie opgehef nie. Die mens het teen God in opstand gekom - hy wou self koning word om onafhanklik van God te regeer. Hy wou nie meer die wêreld tot eer van God regeer nie, maar vir eie belang. Hy het sy koningsmag téén God misbruik.

God wil egter dat die mens weer tot erkenning van sy koningskap gebring word. Die volk word in Eksodus 19:6 beloof dat hulle God in sy koninkryk as priesters sal dien. Vir hierdie doel stuur Hy Christus. Christus kom as die tweede Adam om die koningsheerskappy van God weer deur te voer en om die koningsamp van die mens weer te 
vervul. Sy koningskap kom na vore in sy lewe, lyde en verhoor, en dit bloei volkome in die opstanding en hemelvaart (Postma, 1969: 69). Met die oorwinning van Christus word alles onder sy voete gestel. Hy ontvang alle mag in die hemel en op aarde (Matt. 28:18). Met sy koningskap bring Christus die volle koningsheerlikheid van God na vore. Dit doen Hy deur die mens vry te maak van Satan en om hom sodoende weer as onderkoning te herstel. As tweede Adam vorm Hy 'n nuwe mensheid wat organies aan Hom verbind is en wat eenmaal as konings onder God oor die nuwe aarde sal regeer (Op. 22:5).

Die Skriftuurlike gegewens oor die koningskap soos Postma dit uitgewerk het, het verskeie implikasies. Die belangrikste daarvan is dat die heerskappy van Christus oor die ganse skepping uitkring. Sy heerskappy strek oor kerk en kosmos, wetenskap en kultuur, tegniek en politiek. Die mens en sy wêreld moet hiervoor buig, en dit is die taak van die gelowige om mens en wêreld tot onderwerping te bring in 'n gelowige erkenning van die koningsmag van Jesus Christus. Waar hierdie heerskappy erken word en waar die mens homself daaraan onderwerp, kom daar geregtigheid, vrede en blydskap (Rom. 14:17; vgl. Schmidt, 1969a:583). Hieruit word dit duidelik dat daar ' $\mathrm{n}$ besondere verband is tussen die koninkryk en die mens in dié sin dat die mens nie net daarin 'n plek het nie, maar ook 'n funksie. Ter wille van die argumentasielyn van hierdie artikel word hierop verder ingegaan.

\subsection{Die mens in die koninkryk}

Die koninkryk van God is iets waaraan die mens deel kan kry. Van der Walt (1962:33) stel in hierdie opsig ook die veelsydigheid van die koninkryk wanneer hy sê:

Die Koninkryk kom naby mense (Matt. 3:2; Mark. 1:15 par.; Matt. 4:17, ens.), maar mense kom ook naby die Koninkryk (Mark. 2:30). Dit is van God, van Jesus maar ook van bepaalde mense (Matt. 6:33 par.), word deur hulle verwag (Mark. 5:31 par.), moet ontvang word (Matt. 18:3), word nagelaat (Matt. 25:34), word aan mense gegee (Luk. 12:32) en van mense weggeneem (Matt. 21:43), en deur ander mense verkondig (Mark. 1:14; Luk. 4:43, ens.), vir en deur hulle gesluit (Matt. 16:19; 18:17, ens.), word vir en oor mense opgerig. (Hand. 1:6.)

Van der Walt gee dus 'n duidelike beeld van die verband van die koninkryk tot die mens, maar ook van die feit dat dit in die koninkryk nie net om mense gaan nie. 
Oor die "hoe" van deelgenootskap aan die koninkryk gee die Skrif ook verskillende uitsprake. Dit behoort aan hulle wat arm is van gees (Matt. 5:13), die kinders (Matt. 19:14), aan hulle wat die "dinge van hierdie wêreld" aflê (1 Kor. 6:10), wat die wil van die Vader doen (Matt. 7:21), wat volhard tot die einde toe (Matt. 24:13). Aan die grond van al hierdie uitsprake moet egter die uitspraak van Jesus aan Nikodemus in Johannes 3:3 gestel word. Alleen die wat wéér gebore word, sal die koninkryk van God sien. Samevattend kan in hierdie verband gesê word dat die koninkryk aan almal behoort wat Jesus Christus as die enigste Koning in die geloof omhels en hulle hele lewe onder sy heerskappy en in sy diens stel. Hulle deel in die voorregte van genade, vergewing van sonde, ewige lewe en vrede met God.

Die mense wat tot die koninkryk toetree, word egter nie 'n passiewe deelgenoot nie, maar hulle raak direk by die koms van die koninkryk betrokke. Hulle word die sunergoi (medewerkers) vir die koninkryk (Kol. 4:11). Hulle moet ook voortdurend God se regering oor alles soek. Die beste Skriftuurlike begrip wat gebruik kan word om die mense wat deel is van die koninkryk te beskryf, is die begrip volk van God. Ridderbos (1969:305) sê op goeie grond dat die openbaring van die koninkryk hom rig op die formasie van 'n volk wat die "heilshistoriese" plek van Israel inneem. Dit is egter nie 'n volk in "toekomstige eskatalogiese" sin nie, maar in "toekomstig historiese" sin. Dit gaan om 'n volk wat "die vrugte van die koninkryk voortbring" en wat hulle reeds nou as nuwe volk van God openbaar. Die term volk van God is dus 'n suiwer koninkryksbegrip.

Die volk van God is in openbaringshistoriese sin ook die ekklesia die kerk. Ridderbos (1969:306) sê:

Zo is de ekklesia de gemeenschap dergenen, die als het ware Godsvolk de gaven van het Koninkrijk der hemelen ontvangen, thans bij de verschijning van de Messias reeds in voorlopige zin, eenmaal bij de paroesie van de Zoon des mensen in volkomenheid.

Die ekklesia is dus die volk van God, die burgers van sy koninkryk hulle wat buig onder die heerskappy van Christus en wat poog om alle terreine van die lewe daaraan te onderwerp. Dit word in die volgende deel duideliker aangetoon. Teen hierdie breë agtergrond kan daar nou 'n meer indringende analise gemaak word van die roeping van die kerk in die wêreld. 


\subsection{Die kerk in die koninkryk}

\subsubsection{Die tweërlei betekenis van ekklesia}

Die eksegese van Snyman (1977:35) oor die begrip ekklesia in die Nuwe Testament is baie waardevol en gefundeerd en word in hierdie artikel aan die orde gestel as 'n essensiële bydrae tot die ekklesiologiese model wat vir die bevordering van sosio-politieke versoening in Suid-Afrika voorgestel word. 5 Volgens Snyman (1977:35) kom die woord ekklesia 112 keer in die Nuwe Testament voor. Dit word drie keer in die gewone Griekse betekenis gebruik, naamlik as volksvergadering (Hand. 19:32, 39-40). Dit word twee keer gebruik as aanduiding van die Ou-Testamentiese Israel (Hand. 7:38 en Heb. 2:12). Die ander 107 keer word dit as aanduiding van die gelowiges gebruik. Daar is egter ook hier verskillende nuanserings. Dit word 91 keer gebruik as aanduiding van die samekoms of organisasie van gelowiges oor die algemeen. Snyman onderskei tussen die plaaslike kerk en die universele kerk. Sy konklusie is dat die woord ekklesia in die Nuwe Testament op die gemeenskap van gelowiges dui soos dit verenig en georganiseer is in 'n plaaslike gemeente en soos dit verspreid is oor die ganse aarde. Die ekklesia is dus al die gelowiges saam, maar ook die gelowiges in hulle samekoms (Snyman, 1977: 25). Schmidt (1968b:505), Lindijer (1962:54), De Graaff (1968:59) en Küng (1992:79) kom in hulle onderskeie analises van die begrip ekklesia tot dieselfde konklusie.

Op grond van hierdie analise kan dus gesê word dat die ekklesia in die Nuwe Testament enersyds op die volk van God in sy totaliteit dui, maar andersyds ook op die kerk as vaste organisasie, dit wil sê die kerk soos dit op 'n bepaalde plek tot sigbare vergestalting kom. In die gereformeerde ekklesiologie is daar reeds verskeie kere gepoog om hiervoor ' $n$ aanvaarbare terminologiese onderskeiding te vind. Om moontlike verwarring te voorkom, word in hierdie uiteensetting sover moontlik aangesluit by bekende terminologie. Vir die ekklesia in sy ruimer betekenis, word met die term volk van God volstaan. Vir die kerk as vaste organisasie en soos dit in die geskiedenis as kenbare samelewingsverband funksioneer, word die term geïnstitueerde kerk gebruik.

5 Hoewel die werk van Snyman nie toeganklik was vir die Duitse Rooms Katolieke teoloog Küng nie, is dit opmerklik hoe laasgenoemde in sy opspraakwekkende boek (Küng, 1992) tot dieselfde gevolgtrekkings kom as wat Snyman vroeër gekom het. Die wye reaksie wat sy boek uitgelok het, bewys dat Snyman se eksegese hoog aangeslaan behoort te word, veral in die omskrywing van 'n relevante ekklesiologiese model vir vandag. 


\subsubsection{Die funksie van die geïnstitueerde kerk}

Duvenage (1970:210-211) sê in 'n latere werk dat daar by die bepaling van die roeping van die geïnstitueerde kerk binne die konteks van die koninkryk drie sake is wat as prinsipiële uitgangspunte moet geld. Hierdie uitgangspunte is:

- Die soewereiniteit in eie kring van die geïnstitueerde kerk. Die geïnstitueerde kerk moet rekening hou met 'n eie bevoegdheid. Die geïnstitueerde kerk moet nie poog om mee te werk met alles wat te make het met ander samelewingsverbande nie (vgl. ook Duvenage, 1962:245).

- Die vervlegting van samelewingsverbande. Die taak van die geïnstitueerde kerk moet, net soos die ander Christelike samelewingsverbande, afgestem wees op die realisering van die gesag van Christus, dit wil sê op die bevordering van Christelik-etiese beginsels. As dit reg verstaan word, sou die taak ook die realisering van sosio-politieke versoening in die samelewing insluit.

- Die geïnstitueerde kerk moet nie poog om alleen die draer van die Woord of die konfessie te wees nie. So 'n pretensie reduseer die rol van ander Christelike samelewingsverbande en gelowiges op hulle eie lewensterreine en lei tot kerklike institusionalisme.

Hierdie beginsels is belangrike beginsels waarmee rekening gehou moet word in die formulering van die funksie van die geïnstitueerde kerk. Wanneer die geïnstitueerde kerk se soewereiniteit in eie kring geskend word, lei dit tot deformasie van die kerk, aldus Dooyeweerd.

Die funksie van die geïnstitueerde kerk lê eerstens in die versterking van die geloof van die gelowiges deur die amptelike diens van Woord, sakramente en die gereelde beoefening van die sigbare verbondsgemeenskap in die plaaslike kerk as manifestasie van die volk van God. Bright (1963:164) lê 'n belangrike beginsel neer met sy stelling: "The church lives, let it be repeated, in her preaching ...". Hierdie funksie moet die geïnstitueerde kerk vervul in die lig van die drieërlei amp waarin Christus die evangelie en etiek van die koninkryk van God aan die orde gestel het. Christus het gewerk as Profeet, Priester en Koning. Op grond hiervan moet die geïnstitueerde kerk op sy gebied en die gelowiges in hulle amp as gelowiges binne die verskillende georganiseerde verbande ook profeties, priesterlik en koninklik besig wees. Hierdie model is ná die Reformasie deur veral Beza en Milton gebruik vir hulle fundering van die Christelike staat en die verhouding tussen kerk en staat (Witte, 2007:81, 209). 
Die koninklike roeping van die geïnstitueerde kerk behels dat hy deur die bediening van die Woord en sakramente die koningskap van Christus moet proklameer. Die profetiese roeping behels die verkondiging van die verlossing in Jesus Christus en die oordeel oor die ryk van Satan. Die priesterlike roeping behels die bediening van die liefde van Christus deur middel van die diens van barmhartigheid. Die optrede van die geïnstitueerde kerk moet dus met hierdie unieke roeping korrespondeer. Die geïnstitueerde kerk mag nie funksies van ander Christelike samelewingsverbande oorneem nie soos byvoorbeeld van 'n Christelike politieke party of van Christelike kultuurverenigings nie. Dit is daarom nie die taak van die geïnstitueerde kerk om hom op die gebied van die partypolitiek of kultuurverenigings te begewe nie. Op sy eie gebied moet hy vir die koms van die koninkryk werk. In die uitoefening hiervan is die kerk soewerein in eie kring. Wanneer hierdie funksies van hom ontneem word, of wanneer nuwe funksies daaraan toegevoeg word, lei dit tot deformasie.

Kragtens die beginsel van die vervlegtheid van die verbande staan die kerk egter nie los van die ander verbande nie. As volk van God stry die gelowiges immers saam in al die onderskeie intermenslike relasies vir die koms van die koninkryk. Die roeping van die geïnstitueerde kerk is hieraan verbind. De Graaff (1968:77) verduidelik hierdie verband soos volg: Daar is 'n noue band tussen die geïnstitueerde kerk en die volk van God. Die geïnstitueerde kerk moet fundamentele aanwysings alleen uit die Woord gee. Hierdie aanwysings moet weer deur die gelowiges in ander verbande gepositiveer word.

Volgens Duvenage (1970:212) kan die verband mooi verduidelik word met die beeld van 'n kragstasie. Soos die kragstasie energie opwek om krag en lig in 'n stad te bring, so moet die geïnstitueerde kerk deur die diens van Woord en sakramente die gelowiges opwek om lig - die Lig van die evangelie en die etiek van die koninkryk - te bring binne al die verbande waarin hulle aan die koms van die koninkryk werk. Die geïnstitueerde kerk se koninkryksarbeid is om deur die amptelike diens van Woord en sakramente die gelowiges te bewapen vir hulle koninkryksarbeid binne die samelewingsverbande (vgl. ook Ef. 4:11).

Samevattend kan dus gesê word dat die funksie van die geïnstitueerde kerk in die versterking van die geloof (geloofsywer) van gelowiges geleë is deur die amptelike bediening van die Woord en sakramente in koninklike, profetiese en priesterlike hoedanigheid. So dien die kerk terselfdertyd as kragstasie om die gelowiges te 
versterk om in die amp van die gelowige binne die georganiseerde samelewingsverbande, op eie gebied, die koms van die koninkryk te soek. As die geïnstitueerde kerk meer as dit opeis of minder as dit doen, is dit 'n gedeformeerde kerk. Hierdie werk geskied primêr in die plaaslike kerk. Plaaslike kerke kan egter ook 'n kerkverband vorm. Hulle kan dan in gebiedsfeer, streeksfeer, nasionale sfeer en internasionale sfeer die werk van die koninkryk doen as kragstasies wat gelowiges toerus om die beginsels, voortvloeiend uit die gesag van Christus, konkreet in die volle lewe toe te pas in die verskillende samelewingsverbande waarin hulle funksioneer.

Die beeld van die geïnstitueerde kerk as 'n kragstasie wat deur die bediening van die evangelie en die gesag van Christus gelowiges toerus om binne die samelewingsverbande hulle roeping te vervul, is 'n bruikbare beeld om as basis te gebruik vir die vraag wat aan die begin van hierdie artikel aan die orde gestel is. Die vraag het gelui: Watter ekklesiologiese model bied die ruimte vir die gereformeerde teologie om as gefundeerde en probleem-oplossende teologie sosio-politieke versoening in Suid-Afrika vandag te bevorder? As antwoord word die beeld van die geïnstitueerde kerk as kragstasie van die koninkryk aangebied. Die praktiese implementering van die model word ten slotte bespreek.

\section{Riglyne vir die rol van die kerk in sosio-politieke versoening in Suid-Afrika volgens hierdie ekklesiologiese model}

Dit is nie die bedoeling van hierdie artikel om 'n breedvoerige teologie en etiek van versoening aan te bied nie. Dit is reeds in 'n ander artikel gedoen (vgl. Vorster, 2009). Die resultate van daardie studie word hier opsommend weergegee en dan word veral gelet op die implikasies van die voorgestelde ekklesiologiese model vir die geïnstitueerde kerk se bevordering van versoening in Suid-Afrika.

$\mathrm{Na}$ sy behandeling van die skakering van Skriftuurlike begrippe om die versoening "in Christus" en die implikasies daarvan te verduidelik, kom Schwöbel (2003:19) tot die gevolgtrekking dat die versoening "in Christus" in ses stellings saamgevat kan word. Hierdie ses stellings kan die boublokke van die Christelike versoeningsgedagte genoem word. Vir die doeleindes van hierdie studie is sy gevolgtrekking belangrik en dit word kortliks verduidelik.

- Versoening is noodsaaklik omdat die mensheid dood is in die sonde en daardeur vyande van God, mekaar en die skepping ge- 
word het. Hierdie vyandskap bring die mensheid en alle dinge onder die oordeel van God. God wil egter nie die mensheid en die skepping aan vernietiging oorgee nie en beloof herstel.

- Alleen God kan die herstel teweegbring. Hy wil dit doen deur die vyandskap te deurbreek en versoening te bewerk. Daarmee demonstreer Hy sy onpeilbare liefde aan gebroke sondaars en mense wat in vyandskap met Hom leef.

- Die versoening vind plaas op grond van die soenoffer van Christus aan die kruis. Hierdie soenoffer van Christus aan die kruis is die diepste fondament van die versoening en 'n uitdrukking van die liefde van God vir goddelose mense en die gebroke wêreld.

- Die vryspraak van God as gevolg van die soenoffer van Christus kan slegs op een manier deur die mens toegeëien word, naamlik deur geloof. Daarom word die mens deur die geloof regverdig verklaar en verander die gelowige van 'n doemwaardige mens tot 'n kind en erfgenaam van God.

- God se versoening deur die dood van Christus vestig 'n voortdurende verhouding van vrede tussen gelowiges en die lewende Christus. Gelowiges kan daarvan seker wees dat hulle vrygespreek is van die finale oordeel en dat hulle op die finale verheerliking kan hoop. Ook die gebroke interpersoonlike verhouding word in beginsel heelgemaak, asook die mensheid se versteurde verhouding met die skepping. Versoening vestig shalom (Langmead, 2008:9).

- Hierdie vrede bied hoop en die hoop is 'n gawe van die Heilige Gees en is die lewensbanier van gelowiges. Die versoening gee dus aan die gelowiges nuwe rigting uit die woestyn van vyandskap en gebroke verhoudings na 'n nuwe versoende gemeenskap wat in 'n hegte verhouding met God, met mekaar en met die skepping leef. Gelowiges is daarom geroepe om vanuit die nuwe verhouding met God sondige verdeeldheid teen te werk en gebroke verhoudings heel te maak.

Uitgaande van die ekklesiologiese model wat hierbo in die lig van die reformatoriese filosofiese en teologiese tradisies uiteengesit is en waarin die geïnstitueerde kerk as die kragstasie van die koninkryk gesien word, kan die volgende stellings gemaak word oor die roeping van die kerk ten opsigte van die sosio-politieke betrokkenheid van die kerk in Suid-Afrika vandag. 
- Versoening moet in die eerste plek sigbaar uitdrukking vind in die geïnstitueerde kerk, dit wil sê in die plaaslike kerk en die kerklike vergaderings. Die kerk as versoende gemeenskap is 'n eksemplariese gemeenskap. Dit beteken dat die kerke in hulle bestaanswyse ' $n$ voorbeeld moet wees van wat ware versoening met God en met mekaar beteken. Die kerk is 'n gemeenskap wat alle sosiale gebrokenheid soos rassisme, tribalisme, xenofobie, seksisme, homofobie, klassestryd en etnosentrisme oorbrug en mense saambring in die gemeenskap van geloof. As sodanig moet kerke in die samelewing die uitstalvenster wees van hoe mense met mekaar kan saamleef en saam kan bestaan (vgl. Vorster, 2004:86). Barth (1946:33) verwoord hierdie standpunt wanneer hy skryf oor die rol wat die kerk moet speel ten opsigte van die staat. Hy sê "der rechte Staat muss in der rechte Kirche sein Urbild und Vorbild haben". Dieselfde kan ook gesê word van die rol van die kerk ten opsigte van versoening in die samelewing. Die kerk moet 'n sigbare voorbeeld wees van 'n versoende gemeenskap.

- Die kerk moet versoening verkondig in die prediking in die plaaslike kerk en in die getuienis van kerklike vergaderings. Hierdie roeping beteken in die eerste plek dat die versoening as die werk van die drie-enige God moet verkondig word: "Human moral action is subordinate to divine saving action" (Webster, 2003: 113). Die evangeliserende rol van die kerk, dit wil sê, die roeping om mense op te roep om hulle met God te laat versoen, moet voorop staan in die kerk se agenda van samelewingsbetrokkenheid. Die kerk is en bly eerstens 'n evangeliserende gemeenskap. Bright (1963:164) beklemtoon hierdie prioriteit met sy uitspraak: "The church lives, let it be repeated, in her preaching, always has and always will". Stott (1982:15) verdedig dieselfde standpunt met sy stelling:

Preaching is indispensable to Christianity. Without preaching, a necessary part of its authenticity has been lost. For Christianity is, in its very essence a religion of the Word of God.

In evangelisering vervul kerke hulle primêre roeping ten opsigte van alle mense en spesifiek ten opsigte van versoening.

- Versoening met alle mense is egter ook 'n opdrag aan gelowiges. Gelowiges het die roeping om, as die "kragdrade" van die koninkryk, die etiese beginsels wat voortvloei uit God se versoeningshandeling in die samelewing te bevorder en te realiseer. Die etiese beginsels sluit in vrede, reg en geregtigheid, liefde, sorgsaam- 
heid en barmhartigheid. In situasies van konflik moet mense geleer word dat skuldbelydenis, berou, restitusie en straf inherent deel is van die proses van herstel van verhoudings. Schreurs (2007:141) sê dat die kerklike begrippe confessio oris, contritio ordis en satisfactio operis, wat voorwaardes is vir versoening in religieuse sin, ook van toepassing gemaak kan word vir versoening in sosio-politieke sin. Henzel (2008:17) sê "the message of reconciliation must be transposed into political and economic terms". Newlands (2006:144) bepleit dieselfde saak in sy onlangse publikasie. So ' $n$ transponering van Christelike begrippe in die sosio-politieke arena is volgens Henzel moontlik juis omdat alle mense die skeppingsgawes het as gevolg van die mens se beeldskap van God. Op grond van die versoening "in Christus" kan gelowiges dus die vereistes van 'n versoeningsproses in die samelewing indra. Hierdie vereistes is dat die waarheid oor 'n slegte verlede blootgelê moet word; dat oortreders berou moet betoon en skuld moet erken; dat mense bereid moet wees om foute reg te stel en opofferings te maak ter wille van vrede en 'n beter sosio-politieke bedeling vir almal (vgl. Webster, 2003:116).

- Gelowiges wat in 'n nuwe verhouding tot God lewe en wie se verhoudingslewe deur die geloof in Christus radikaal vernuwe is, moet ook die nuwe verhoudings uitleef deur 'n nuwe verhouding van vrede aan andere aan te bied (Rom. 12:18). Hulle moet die inisiatief neem om versoening in gebroke verhoudings te bewerk. Versoening moet in vredesinisiatiewe uitmond (Langmead, 2008: 12).

Reconciliation ... really embodies an ethic. It embodies a theology that is alive, that interacts with the culture around it and responds actively to the things that are happening, especially to the violence that is happening. (Johnson, 2005:28.)

Gelowiges moet die hand van liefde uitsteek ook na hulle wat nie in God glo nie. Hulle moet dus die ywerige agente van versoening in die samelewing wees deur self vrede en geregtigheid vir alle mense te soek.

- Kerke en gelowiges se versoeningsrol in 'n siek samelewing lê dus daarin om God se versoening in Christus te verkondig en te vergestalt. Hulle moet mense oortuig om die dieper etiese beginsel wat uit Christus se versoeningswerk voortvloei so toe te pas dat die wonde wat deur menslike onversoenlikheid ontstaan het, genees kan word. 
Die beredenering van die wese en roeping van die kerk binne die perspektief van die koninkryk van God, dit wil sê die beskrywing van die kerk as die kragstasie van die koninkryk, bied 'n bruikbare ekklesiologiese model waardeur die gelowiges se roeping tot sosio-politieke versoening in Suid-Afrika vandag effektief uitdrukking kan vind. Sonder sodanige model kan kerke hulle roeping tot sosio-politieke versoening omseil deur óf op te gaan in wêreldmydende spiritualisme, óf in 'n sekulêre politieke aktivisme. Hierdie model laat die kerk kerk bly, maar gee tog ook ruim geleentheid vir die kerk om by sosio-politieke versoening betrokke te wees.

\section{Geraadpleegde bronne}

BARTH, K. 1946. Christengemeinde und Bürgergemeinde. Zürich: Evangelisher Verlag.

BOSCH, D.J. 1991. Transforming mission: paradigm shifts in theology of mission. New York: Mary-Knoll.

BOTHA, E. 1971. Sosio-kulturele metavrae. Amsterdam: Buijten \& Schipperheijn.

BRIGHT, J. 1963. The kingdom of God. New York: Abingdon.

BUYS, P.W. 1970. Die ekklesiologiese onderskeiding: organisme en instituut as antwoord op die problematiek van die Volkskerk: 'n historiese, prinsipiële en praktiese studie. Potchefstroom: $\mathrm{PU}$ vir $\mathrm{CHO}$.

CAIRNS, E.E. 1982. Christianity through the centuries. Grand Rapids: Zondervan.

CALVYN, J. 1949. Institutie, of onderwijsing in de Christelijke godsdienst. Vol. 3. Delft: Meinema.

COERTZEN, P. 1991. Gepas en ordelik. Pretoria: Raad vir Geesteswetenskaplike Navorsing.

CONE, J.H. 1970. A black theology of liberation. Philadelphia: Lippencott.

COX, H. 1967. De stad van de mens: het levenspatroon van de moderne wereld in theologisch perspectief. Utrecht: Ambo.

DE GRAAFF, A. 1968. The educational ministry of the church: a perspective. Grand Rapids: Craig.

DE KLERK, B.J. 1987. Die Heilige Gees en die verhouding Skriflesing, prediking en gebed in die erediens. Potchefstroom: $\mathrm{PU}$ vir $\mathrm{CHO}$.

DOOYEWEERD, H. 1936. De wijsbegeerte der wetsidee. Deel 3. Amsterdam: Paris.

DU PLOOY, A. LE R. 1997. The foundation and relevance of reformed church polity as a theological science. Studia historiae ecclesiasticae, 23(1 \& 2):169-198.

DU TOIT, S. 1969. Die koninkryk van God in die Ou Testament. (In Du Toit, S. Die koninkryk van God. Potchefstroom: Pro Rege. p. 11-33.)

DUVENAGE, S.C.W. 1962. Kerk, volk en jeug: die verhouding van kerk tot volk. Zaandijk: Heijnis.

DUVENAGE, S.C.W. 1969. Die verhouding van kerk en koninkryk. (In Du Toit, S. Die koninkryk van God. Potchefstroom: Pro Rege. p. 113-132.)

DUVENAGE, S.C.W. 1970. Die geïnstitueerde kerk en die toekoms van die Afrikaanse volkskultuur. Koers, 37(3 \& 4):206-218. 
FIERRO, A. 1977. The militant gospel: an analysis of contemporary political theologies. London: SCM.

FLOOR, L. 1974. Die koninkryk van God en die vernuwing van die maatskappy. Potchefstroom: Pro Rege.

GUTIERREZ, G. 1974. A spirituality of liberation. (In Kee, A. A reader in political theology. London: SCM. p. 95-100.)

GUTIERREZ, G. 1985. A theology of liberation. New York: SCM.

HENZEL, J. 2008. From discord to concord. European journal of theology, 17(1):13-18.

HEYNS, J.A. 1977. Die kerk. Pretoria: NG Kerkboekhandel.

HEYNS, J.A. 1986. Teologiese etiek. Deel 2: Sosiale etiek. Pretoria: NG Kerkboekhandel.

JOHNSON, D.J. 2005. Watu Wa Amani (People of Peace): an African theology of liberation and reconciliation from the historic peace churches in Africa. Brethren life and thought, 52(10):16-31.

KÖNIG, A. 1988. Koninkryksteologie of verbondsteologie? Hervormde teologiese studies, 44(2):355-364.

KÜNG, H. 1992. The church. Kent: Burns \& Oates.

KUYPER, A. 1892. E Voto Dordraceno. Kampen: Kok.

KUYPER, A. 1909a. Encyclopedie der heilige Godgeleerdheid. Deel 2. Kampen: Kok.

KUYPER, A. 1909b. Encyclopedie der heilige Godgeleerdheid. Deel 3. Kampen: Kok.

KUYPER, A. 1943. Calvinism, six Stone Foundation lectures. Grand Rapids: Eerdmans.

LADD, G.E. 1961. The gospel of the kingdom of God. Grand Rapids: Eerdmans.

LANGMEAD, R. 2008. Transformed relationships: reconciliation as the central model for mission. Mission studies, 25(1):5-20.

LINDIJER, C.H. 1962. Kerk en koninkryk. Amsterdam: Ten Have.

MOLTMANN, J. 1965. Theologie der Hoffnung: Untersuchungen zur Bergründung und zu den Konsequenzen einer christlichen Eschatologie. München: Kaiser.

MOLTMANN, J. 1994. Christianity in the third millennium. Theology today, 51(1):75-89.

MOLTMANN, J. 2008. A broad place: an autobiography. Minneapolis: Fortress.

NEWLANDS, G. 2006. Christ and human rights: the transformative engagement. Hampshire: Ashgate.

POSTMA, J. 1969. God drie-enig as koning en Christus as koning. (In Du Toit, S. Die koninkryk van God. Potchefstroom: Pro Rege. p. 59-74.)

PRAAMSMA, L. 1981. The church in the twentieth century. Vol. 7. Ontario: Paideia.

RIDDERBOS, H. 1969. The coming of the kingdom. Philadelphia: Presbyterian and Reformed Publishing.

SCHILDER, K. s.a. De kerk. Kampen: Broederweg 6.

SCHMIDT, K.L. 1969a. Basileia. (In Kittel, G., ed. Theological Dictionary of the New Testament. Grand Rapids: Eerdmans. p. 579-593.)

SCHMIDT, K.L. 1969b. Ekklesia. (In Kittel, G., ed. Theological Dictionary of the New Testament. Grand Rapids: Eerdmans. p. 501-536.)

SCHREURS, N. 2007. Verzoening in Bijbelse en huidige crisissituaties. International journal in philosophy and theology, 68(2):123-147. 
SCHWÖBEL, C. 2003. Reconciliation. (In Gunton, C.E. The theology of reconciliation. London: Clark. p. 13-38.)

SHAULI, R. 1969. Uitdaging aan kerk en maatschappij. Baarn: Bosch \& Keuning.

SMIT, D.J. 2007. Essays in public theology: collected essays. Cape Town: Sun Media.

SNYMAN, W.J. 1977. Nuwe en ou dinge, uit die skat van die Koninkryk. Potchefstroom: Pro Rege.

SPOELSTRA, B. 1989. Gereformeerde kerkreg en kerkregering: 'n handboek by die kerkorde. Hammanskraal: Hammanskraalse Teologiese Skool.

STOTT, J.R.W. 1982. I believe in preaching. London: Hodder \& Stoughton.

STRAUSS, P. 1992. Die sinode: 'n eie kerklike gesag? Nederduitse Gereformeerde teologiese tydskrif, 33(2):188-197.

VAN DER WALT, B.J. 2008a. Onderweg na 'n Christelike samelewingsbeskouing: bybelse grondslae en historiese ontwikkeling. In die Skriflig, 42(1):1-23.

VAN DER WALT, B.J. 2008b. 'n Reformatoriese samelewingsfilosofie: 'n sistematiese uiteensetting, kritiese evaluering en praktiese toepassing. In die Skriflig, 42(3):499-529.

VAN DER WALT, T. 1962. Die koninkryk van God - naby! Kampen: Kok.

VAN DER WALT, T. 1969. Die voleinding van die koninkryk. (In Du Toit, S. Die koninkryk van God. Potchefstroom: Pro Rege. p. 96-112.)

VAN ROOY, J.A. 1976. Verbond en koninkryk. In die Skriflig, 38(2):6-8.

VAN WYK, J.H. 1991. Moraliteit en verantwoordelikheid: opstelle oor politieke etiek. Potchefstroom: PU vir $\mathrm{CHO}$.

VERKUYL, J. 1971. Breek de muren af! Om gerechtigheid in de rassenverhoudingen. Baarn: Bosch \& Keuning.

VORSTER, J.M. 1993. Kuyper se ekklesiologie en die interpretasie van kerklike sake in Art. 30 van die Kerkorde van die GKSA. In die Skriflig, 27(2):215229.

VORSTER, J.M. 2004. Ethical perspectives on human rights. Potchefstroom: Potchefstroom Theological Publications.

VORSTER, J.M. 2009. Versoening "in Christus" en sosio-politieke versoening. Nederduitse Gereformeerde teologiese tydskrif. (Moet nog verskyn.)

VORSTER, N. 2006. Transformation in South Africa and the Kingdom of God. Hervormde teologiese studies, 62(2):731-753.

WALKER, W. 1992. A history of the Christian church. Edinburgh: Clark.

WEBSTER, J. 2003. The ethics of reconciliation. (In Gunton, C.E. The theology of reconciliation. London: Clark. p. 109-123.)

\section{Kernbegrippe:}

ekklesiologiese model

koninkryk van God

Kuyper

samelewingsleer

sosio-politieke versoening 


\section{Key concepts:}

ecclesiological model

kingdom of God

Kuyper

perspective on social life

socio-political reconciliation 